\title{
The role of happiness components in educational performance and self-esteem in primary high school's female students of Shiraz Education district 4 in the academic year 1394-1395
}

\author{
Sima ZAREIYAN ${ }^{1}$, Abdol Mohammad TAHERI ${ }^{2, *}$ \\ ${ }^{1}$ Master's Student in Educational Management, Islamic Azad University of Shiraz \\ ${ }^{2}$ Associate Professor and Faculty Member, Islamic Azad University of Shiraz, Department of \\ Educational Management, Shiraz, Iran
}

\begin{abstract}
The main purpose of available research is to determine the role of happiness components in educational performance and self-esteem of primary high school female students of Shiraz education district 4 in the academic year 1394-1395. The research method is survey-descriptive and correlational. The research statistical community was including all primary high school female students of 4 district Shiraz, 6000 persons. 354 persons was chosen accidently according to MORGAN table. To achieve this purpose, the multi stage cluster sampling was used. The tools have been used in the research are rejuvenating certain questionnaire and also standard questionnaires for determining the educational performance and self-esteem. After presenting the experts opinions and redundancy_the validity content was reported respectively by the happiness questionnaire 0.86 , the educational performance questionnaire 0.79 , and the self-esteem questionnaire 0.85 . The results achieved by hypothesis test shows that happy schools are not effective on students' educational performance significantly. The autocratic management method is effective on the students' educational performance. The personal factors, educational factors, socio-cultural factors, skeletal factors, the participatory management method were not effective on students' educational performance. The hypothesis also shows that the autocratic management method can predict the educational performance variable compared to other components. Finally, the hypothesis shows that the participatory management method and autocratic management method are effective on students' self-esteem and other components are not effective on selfesteem and the independent variable of autocratic management method, participatory management method and educational factors can predict self-esteem significantly.
\end{abstract}

Keywords: happiness, educational performance, self-esteem, primary high school

\section{Introduction}

Happiness is one of the basic requirements of life, it is one factor for growth and success. The universe is so that it provides happiness causes for human. Jovial spring, beautiful waterfalls, colorful flowers, scene of sunrise, gentle rain, cute birds and their singing and many more

\footnotetext{
${ }^{*}$ Corresponding author: this article is retrieved of master thesis of educational management. Email: vahid_taahh2010@yahoo.com
} 
amazing phenomena's around the world, all bring us happiness. Creating joy and happiness is one of the most effective ways for increasing mental health of society. One of the essential principles which is more discussed recently is the rejuvenating schools subject. [1]

Satisfaction happiness and joy are the mental health index. Joy in schools is not for one reason and of course a collection of factors influences that, and this collection of factors and components effect on educational performance and mental factors such as self-esteem. The forefront of education in recent century is learning the joy of living must be trained to the students, therefore it must be believed that lasting growth is depended on lasting happiness and such happiness must be created and managed in schools. Cheerful school is able to present desire to live to the students. Joy and happiness is one of the basic ethos in person's life and plays an important role in his mental and social life framework. [2]

Nowadays, joy and happiness in educational environment has magnificent role in case of quality and planning education, somehow enjoying the education, activating sense of curiosity and increasing creativity in students, are significantly related to their educational environment status. Creating joyful educational environment for students has been discussed among educational planners for many years. This question is one of the basic requirement among students, cause of children are visual!

They enjoy such environment and atmosphere in which joy and happiness is suggested and their scientific development will be significant because of increasing motivations.

Such environment will be joyful to them just if appropriate educational facilities and conveniences could actuate sense of curiosity in learners and attract them. Therefore, it is necessary for all parents and teachers and also all related education heads to try to make the educational centers as joyful and attractive environment so that the students' educational development will increase. To achieve the realization of desires related to the rejuvenating schools in case of students' educational performance, there should be a serious revolution in managers' attitude and responsible of education system and educational planning according to the universal standards. However, happiness is a characteristic affected by nature properties and characteristics, especially introspection and extroversion. [3]

So it seems that failures rarely cause outbreak of negative affection in cheerful persons and every failure could be treated as an experience for success optimistically. On the other side, happiness is also affected by experiences and learnings. In fact, happiness is such a wealth, the wealth could be increased or could be lost. Happiness which is common goal for all people and everybody tries to achieve, is just assessment of persons from themselves and their life.

People who have the power of internal emotion control, rarely are exposed to depression and negative effects, they show more self-regulatory and coping skills, and they have higher self confidence and self-esteem compared to those people who have exterior sense of control. Moreover, sense of control is related to other health component which is included health results in .... And better educational performance in children and adolescents. [4]

Spiritual expansions.... and laughing face are the basic factors in growth and efflorescence for youths and also foundation for drain obsessions and spiritual pressures. Joy and spiritual 
expansions, is one of the effective parameters in forming positive personality of children and teenagers and vice versa anxiety and stress is an important factor to stop talents [5]

Since happiness, mobility and joy are the new generation property and agrees his innate nature and circumstances, but weakness, indolence, isolation, laxation depression, and withered state, all are big blights and a huge barrier for in front of growth and creativity and efficiency of young generation. Preventing joy and freshness in youths and preventing their accession of feelings and emotional tensions is cause of frustration and outbreak of humility and psychological obsessions. Sometimes failures and disappointment cause discouragement in solving problems and disability in learners. Recently industrial world, complexity in relationships, the amount of failures and people mental pressures have increased and would make a bitter life for somebodies. Some other people are not satisfied for primary necessaries and new requirements are born added to previous requirements. And students are not exceptions among these and they are carrying more complicated duties compared to previous generations and they are convinced to observe new educational planning. By acquisition of joyful methods in educating and curriculum of learners, we could create a satisfying environment for students, moreover, many other problems are .... such as absence, delay, impatience and illness feeling in classroom, physical and spiritual ills and finally dropout.

We can provide an environment in which effective learning facilities would be considered. Therefore, attention to the effect of breezy methods in educational planning for different education periods seems to be necessary. [6]

Development of each country is directly related to development of science and technology. [7]

Science development is not achieved unless people would be up brought thoughtful and creative. Educational development is not only effective in development and prosperity in a country, but also it leads to find appropriate job and situation and finally efficient payments. Society and the family will look respectfully to the students who are successful and they will present in society by better joyful spirit and besides, the huge costs caused by dropout which is imposed to educational system will decrease.

In such situation which many town houses are converted to little apartments and lack of sufficient space for children to play, the least could be done for providing physical and spiritual health of students is creating breezy environment in schools, since students pass their hours in schools. Rejuvenating schools must be found in apparent dimensions and also spiritual dimension. Considering above discussions, researcher has been following the role of rejuvenating school's components in educational performance and self-esteem in female students.

Therefore, the hypothesis in the research are a s bellow:

1) Rejuvenating schools (personal factors) effects on student's educational performance.

2) Rejuvenating schools (educational factors) effects on student's educational performance.

3) Rejuvenating schools (socio-cultural factors) effects on student's educational performance.

4) Rejuvenating schools (skeletal factors) effects on student's educational performance. 
5) Rejuvenating schools (participatory management method) effects on student's educational performance

6) Rejuvenating schools (autocratic management method) effects on student's educational performance

7) Rejuvenating schools (personal factors) effects on students' self-esteem.

8) Rejuvenating schools (educational factors) effects on students' self-esteem.

9) Rejuvenating schools (socio-cultural factors) effects on students' self-esteem.

10) Rejuvenating schools (skeletal factors) effects on students' self-esteem.

11) Rejuvenating schools (participatory management method) effects on students' self-esteem.

12) Rejuvenating schools (autocratic management method) effects on students' self-esteem.

And also many researchers have done related researches, which could be pointed as bellow:

GHOLAMI \& CHARI (1390) in such research as predicting happiness of guidance school students according to their perception of the teacher's expectations, they investigated the way of interaction between teacher and self-efficiency. the results indicated that some interaction dimensions between students and the teacher directly predict self-efficiency [8]

JAFARI \& TALEBZADEH (1389) considered the joy and happiness in primary schools of Tehran by presenting a model. The results showed the importance of physical factors, emotional factors, social factors, personal factors and educational factors in joy and happiness, according to the teachers. [9]

ZAREI MATIN et al. (1388) considered the role of university in creating the effective factors on happiness. The results showed people who live happily increase their focus and they are always successful and also it effects on cognitive processes such as memory, problem solving and intellectual flexibility [10]

LWIE et al. (2016) considered that_parent's obligation and relationship to school effects on the students' educational and emotional performance, their research as the relation between educational and emotional performance for primary students in China. [11]

MAHOON et al. (2010) in their research as happiness relation to gender and health in early stages of development, considered that there is no difference between males and females' happiness while there is considerable difference between happiness and health variables for all. [12]

EWISHI et al. (2010) researched as culture, interpersonal perception and happiness in social interactions, the results showed that emphasize on the persons' important personality aspects leads to his happiness and cultural differences appear in different personality aspects. [13] 


\section{The research method}

Since the researcher is considering the effect of happiness school's components on educational performance and the students' self-esteem, the research method is descriptive-correlation in terms of nature and practical in terms of goal.

\section{Research community}

Research community includes all primary high_school female students of district 4 Shiraz in the academic year 1394-1395, which is 6000 persons according to the statistics obtained from educational experts of the primary high school of 4 district Shiraz. For determining the number of samples, MORGAN table is used and according to the table,_sample_size is 363 persons. Multi stage cluster sampling method is used due to the research community.

\section{Information gathering tools}

Three questionnaires are used in the research as bellow:

TAHERI primary certain questionnaire for rejuvenating schools (1395): this questionnaire has been designed by 73 questions and LIKERT Spectrum in 5 axis of personal factors, educational factors, socio-cultural factors, skeletal factors, management factors (participatory and autocratic) .and students will express their opinions about such factors. The questionnaire has been designed by using previous studies and considering theoretical bases. (OXFORD questionnaire OHI)

The educational performance questionnaire ETP by FAM \& THAILOR (1999): This questionnaire measures the 5 scopes related to educational performance by 48 questions. The five scopes are as bellow:

Self-efficiency, emotional effects, lack of controlling consequences, planning, and motivation.

COPPER SMITH self-esteem questionnaire: this questionnaire contains 58 questions which describes the feelings, beliefs, or the person's reactions. each sub-scale clauses are as bellow: general scale 26 clauses, social scale 8 clauses, familial scale 8 clauses, educational or occupational scale 8 clauses, and the lie scale 8 clauses.

All three above questionnaire have validity content according to experts votes and also their stability is respectively: $0.86,0.79,0.85$

\section{Data analysis method}

Part of analysis of this research is considered by the destructive statistics and the other part by inferential statistics. In descriptive part, statistic such as frequency, cumulative frequency, average and median are considered .and in inferential part, person's correlation test and regression are used to consider the research variables.

\section{Variables definition}

Happiness: happiness is one of the basic requirements in life and that is a factor leads to growth and success. Life is defined by joy and happiness and students would be self-sufficient and 
quickly develop educationally. Happiness is something called "fixed extroversion". happiness is a quality which is influenced by nature and personality features especially introspection and extroversion. [3]

Educational performance: means increasing the learning, increasing the level of acceptable marks of students in their lessons and grades. So, if the educational expected level met, the ministry of education will achieve the predetermined goals in educational planning. [14]

Self-esteem: identifies the most important aspect of people personality, which points to the recognition of oneself. Teenagers feel important and this will be effective on their health and dynamic.

\section{Results}

Obtained results of available research are as bellow:

- Happiness school's components are effective on student's educational performance.

To consider the relation between rejuvenating variables and student's educational performance, the PIERSON correlation test is used.

Table 1: Correlation coefficient of rejuvenating and educational performance

\begin{tabular}{|l|c|c|}
\hline \multirow{3}{*}{ REJUVENATING } & Correlation coefficient & Educational performance \\
\cline { 2 - 3 } & & 0.015 \\
\cline { 2 - 3 } & significancy & 0.77 \\
\cline { 2 - 3 } & aggregate & 354 \\
\hline
\end{tabular}

According to table.1 the relation between rejuvenating schools and student's educational performance is not significant.

- Happiness school's components are effective on students' self-esteem.

To consider the relation between happiness school's components and students' self-esteem, the PIERSON correlation test is used.

Table 2: Correlation coefficient of rejuvenating and self-esteem

\begin{tabular}{|l|c|c|}
\hline \multirow{2}{*}{ REJUVENATING } & Correlation coefficient & Self-esteem \\
\cline { 2 - 3 } & & 0.027 \\
\cline { 2 - 3 } & significancy & 0.61 \\
\cline { 2 - 3 } & aggregate & 354 \\
\hline
\end{tabular}

According to table 2, the relation between happiness schools and students' self-esteem is not significant. 
- Rejuvenating schools (autocratic management method) is effective on student's educational performance.

To consider this topic, the PIERSON correlation test and regression is used.

Table 3: Correlation coefficient of autocratic management method and educational performance

\begin{tabular}{|c|c|c|}
\hline \multirow{2}{*}{$\begin{array}{c}\text { Autocratic } \\
\text { management } \\
\text { method }\end{array}$} & Correlation coefficient & Educational performance \\
\cline { 2 - 3 } & significancy & 0.151 \\
\cline { 2 - 3 } & aggregate & 0.004 \\
\hline
\end{tabular}

According to table 3 , since the significancy level is 0.004 and it is less than 0.01 , so there is significant relation between autocratic management method and educational performance.

Table 4: Regression coefficient of autocratic management method and educational performance

\begin{tabular}{|c|c|c|c|c|c|c|}
\hline \multirow{2}{*}{\multicolumn{2}{|c|}{ Regression model }} & \multicolumn{2}{|c|}{$\begin{array}{l}\text { Non-standards } \\
\text { regression coefficient }\end{array}$} & \multirow{3}{*}{$\begin{array}{l}\text { Standard } \\
\text { regression } \\
\text { coefficient }\end{array}$} & \multirow{3}{*}{$\begin{array}{c}\text { Statistic (t) } \\
8.302\end{array}$} & \multirow{3}{*}{$\begin{array}{c}\text { Significancy } \\
0.0001\end{array}$} \\
\hline & & Regression & Standard & & & \\
\hline \multirow{2}{*}{$\begin{array}{c}\text { Autocratic } \\
\text { management }\end{array}$} & Consist & 2.022 & 0.244 & & & \\
\hline & $\begin{array}{l}\text { Educational } \\
\text { performance }\end{array}$ & 0.229 & 0.080 & 0.151 & 2.870 & 0.004 \\
\hline
\end{tabular}

According to table 4, since the significancy method is 0.0001 and 0.004 and it is less than 0.01 , so the result of linear regression equilibrium can predict the relation between the two variables of autocratic management method and educational performance.

- The happiness school's components are effective on student's educational performance.

To consider this hypothesis, the PIERSON correlation test is used. 
Table 5: The correlation coefficient of other rejuvenating components and educational performance.

\begin{tabular}{|c|c|c|c|c|}
\hline \multirow{6}{*}{$\begin{array}{l}\text { Educational } \\
\text { performance }\end{array}$} & $\begin{array}{c}\text { Rejuvenating } \\
\text { components }\end{array}$ & $\begin{array}{l}\text { Correlation } \\
\text { coefficient }\end{array}$ & Significancy & Aggregate \\
\hline & Personal factors & 0.091 & 0.067 & 354 \\
\hline & $\begin{array}{l}\text { Educational } \\
\text { factors }\end{array}$ & 0.051 & 0.33 & 354 \\
\hline & $\begin{array}{l}\text { Socio-cultural } \\
\text { factors }\end{array}$ & 00.21 & 0.82 & 354 \\
\hline & Skeletal factors & 0.02 & 0.70 & 354 \\
\hline & $\begin{array}{c}\text { Participatory } \\
\text { management } \\
\text { method }\end{array}$ & 0.092 & 0.083 & 354 \\
\hline
\end{tabular}

According to table 5 , since the significancy level is respectively $0.06,0.33,0.82,0.7,0.08$, so there is no significant relation between the other rejuvenating components and educational performance.

- Rejuvenating components (participatory management method) is effective on students' self-esteem.

To consider this hypothesis, the PIERSON correlation test is used.

Table 6: Correlation coefficient of the participatory management method and self-esteem

\begin{tabular}{|c|c|c|}
\hline \multirow{4}{*}{$\begin{array}{c}\text { Participatory management } \\
\text { method }\end{array}$} & Correlation coefficient & Self-esteem \\
\cline { 2 - 3 } & & 0.254 \\
\cline { 2 - 3 } & significancy & 0.0001 \\
\cline { 2 - 3 } & aggregate & 354 \\
\hline
\end{tabular}

According to table 6 , since the significancy level is 0.0001 and this is less than 0.01 , so it means that there is significant relation between the participatory management method and self-esteem. 
Bulletin de la Société Royale des Sciences de liège, Vol. 86, special edition, 2017, p. 259 - 270

Table 7: Regression coefficient of participatory management method and self-esteem

\begin{tabular}{|c|c|c|c|c|c|c|}
\hline \multirow{2}{*}{\multicolumn{2}{|c|}{ Regression model }} & \multicolumn{2}{|c|}{$\begin{array}{c}\text { Non-standards regression } \\
\text { coefficient }\end{array}$} & \multirow{3}{*}{$\begin{array}{c}\text { Standard } \\
\text { regression } \\
\text { coefficient } \\
--\end{array}$} & \multirow{3}{*}{$\begin{array}{c}\begin{array}{c}\text { Statistic } \\
(\mathrm{t})\end{array} \\
25.348\end{array}$} & \multirow{3}{*}{$\begin{array}{c}\text { Significancy } \\
0.0001\end{array}$} \\
\hline & & Regression & Standard & & & \\
\hline \multirow{2}{*}{ Self-esteem } & Consist & 1.232 & 0.049 & & & \\
\hline & $\begin{array}{c}\text { Participatory } \\
\text { management } \\
\text { method }\end{array}$ & 0.071 & 0.014 & 0.254 & 4.934 & 0.0001 \\
\hline
\end{tabular}

According to table 7, since the significant level is 0.0001 and 0.0001 and that is less than 0.01 , so the result of regression linear equilibrium can predict the relation between the two variables of participatory management method and self-esteem.

- The happiness school's components (autocratic management method) is effective on students' self-esteem.

To consider this hypothesis, the PIERSON correlation test is used.

Table 8: Correlation coefficient of the autocratic management method and self-esteem

\begin{tabular}{|c|c|c|}
\hline \multirow{2}{*}{$\begin{array}{c}\text { Autocratic } \\
\text { Management } \\
\text { method }\end{array}$} & Correlation coefficient & Self-esteem \\
\cline { 2 - 3 } & significancy & 0327 \\
\cline { 2 - 3 } & aggregate & 0.0001 \\
\hline
\end{tabular}

According to table 8 , since the significancy level is 0.0001 and that is less than 0.01 , so it means there is significant relation between autocratic management method and self-esteem.

Table 9: Regression coefficient of autocratic management method and self-esteem

\begin{tabular}{|c|l|c|c|c|c|c|}
\hline \multicolumn{2}{|c|}{ Regression model } & \multicolumn{2}{|c|}{$\begin{array}{c}\text { Non-standards regression } \\
\text { coefficient }\end{array}$} & $\begin{array}{l}\text { Standard } \\
\text { regression } \\
\text { coefficient }\end{array}$ & $\begin{array}{c}\text { Statistic } \\
(\mathrm{t})\end{array}$ & Significancy \\
\cline { 2 - 6 } & $\begin{array}{l}\text { Regression } \\
\text { coefficient }\end{array}$ & $\begin{array}{l}\text { Standard } \\
\text { error }\end{array}$ & & 23.062 & 0.0001 \\
\hline \multirow{3}{*}{ Self-esteem } & Consist & 1.150 & 0.050 & -- & 6.496 & 0.0001 \\
\cline { 2 - 6 } & $\begin{array}{l}\text { Participatory } \\
\text { management } \\
\text { method }\end{array}$ & 0.106 & 0.016 & 0.327 & & \\
\hline
\end{tabular}


According to table 9, since the significancy level is 0.0001 and 0.0001 and that is less than 0.01 , so the result of regression linear equilibrium can predict the relation of the two variables of autocratic management method and self-esteem.

- Other happiness components are effective on students' self-esteem.

To consider this hypothesis, the PRESON correlation test is used.

Table 10: Correlation coefficient of other rejuvenating components and self-esteem

\begin{tabular}{|c|c|c|c|c|}
\hline \multirow{7}{*}{ Self-esteem } & Personal factors & $\begin{array}{c}\text { Correlation } \\
\text { coefficient }\end{array}$ & Significancy & Aggregate \\
\cline { 2 - 5 } & $\begin{array}{c}\text { Educational } \\
\text { factors }\end{array}$ & 0.055 & 0.30 & 354 \\
\cline { 2 - 5 } & $\begin{array}{c}\text { Socio-cultural } \\
\text { factors }\end{array}$ & 0.028 & 0.60 & 354 \\
\cline { 2 - 5 } & Skeletal factors & 0.068 & 0.59 & 354 \\
\hline
\end{tabular}

According to table 10 , since the significancy level is respectively $0.3,0.6,0.6,0.2$, so there is not significant relation between other rejuvenating components and self-esteem.

\section{Results}

Due to the importance of happy space in educational performance and self-esteem and lack of such space in our educational environments, all educational staff are ought to act for revival of this space, However the notable point in this research is that the role and effect of management as a key tool and perform its different methods is much important in removal of obstacles and production a collection of beliefs and attitudes and orient the educational and training politics. observations and studies in recent century have proved that the foundlings of management science are so important and they are practically used and the results are absolutely obvious nowadays.

By testing the two methods of RENESIS LIKERT quadruple management system which means autocratic management and participatory management in the format of rejuvenating factors in schools, notable effects on self-esteem and educational performance of students was observed, but the effects of other aspects of rejuvenating, personal factors, educational factors , sociocultural and skeletal factors indicated notable and impressive effects, because of wide aspects of cultural poverty in schools and the research educational range ,However the autocratic and constructionist management which is much similar to $\mathrm{X}$ hypothesis and scientific management, showed important effects, and therefore it can be concluded that the atmosphere of fear and intimidation reigns at the school organizational levels in female female primary high schools so that there are less encouraging and rewarding clues are seen and the only factor in the relationship between the manager and students and employees is the manager's will and since the school organization controlling and governing is by absolute guide format and warning to 
subordinates and the familial culture and social atmosphere and the environment in which the schools and subjects exist, are consistent with such style ,so this management method could effect on their self-esteem and somewhat their educational performance. the other much notable point is that the participatory and relationship-based management method which is much similar to $\mathrm{Y}$ hypothesis could have some effects on self-esteem, which is the versa vise point of autocratic management and that is another side of management spectrum. so it can be generally concluded that just the management factors are strongly able to have positive effects on selfesteem and educational performance, in rejuvenating schools. And this is evidence for the importance of the role of management and its place. Attention to schools management means attention to the educational environment succulence.

\section{References}

1. BUSS, D. (2000). The evolution of happiness. American psychologist, Vol. 55(1), 1523.

2. Sabaghiyan, Zahra (1384), "school and strengthen the vitality and hope to life" Peyvand magazine 309,310 and 311 P.33 \& 28.

3. Bainbridge, carol .(2010). Intrinsic Motivation Gifted kids. About. Com. Reterived 28 November.

4. EYSENC,MICHAEL.(1375), Happiness psychology" translated by Mehrdad firoozbakht \& Khashayar Beygi. Tehran, Badr.

5. Eskandari, Moharram.(1386) ."the new teaching methods guidance". Rahyaft publications. first edit. Tehran.

6. Kraft, M . (2008). Delegation Von Preiskompetenzan den Verkaufsau Bendienst, eineempirische Analyse ausgewahlter Determinaten and Gestal ungsmoglichkeiten,

Wiesbaden, P.36

7. Chamorro Premuzic, Bennett, B ,\& Furnham, A .(2006). The Happy Personality: Mediational role of trait emotional intelligence, personality and individual differences, 42 , $1633-1639$.

8. Gholami, Somayeh. Hossein Chari, Masoud.(1390) "prediction of students gaiety considering their perception of the teacher's expectation and self-efficiency. Shiraz, Training studies and Learning Publication. Vol 3,NO 1, PP. 83-109

9. Jafari-Parivash. Talebzadeh- Fatemeh.(1389) "presenting a model for joy and happiness in Tehran elementary schools. Journal of educational government and management. Azad University of Garmsar. $4^{\text {th }}$ year (4), Winter.

10. Zarei, Matin. Hassan, Ahmadi Zahrani and Hagh Gooyan ,Zolfa.(1388) "the role of university in creating the effective factors on happiness."Farhang Magazine in Azad University. $13^{\text {th }}$ year (2),Summer.

11. LV,bo .Zhou , Huan, Guo, Xiaolin, Liu, Chunhui, Liu , Zhaomin , and Luo, Liang(2016), The relationship between academic achievement and the emotional well-being of elementary school children in China: The moderating role of parent-school communication. Frontiers in psychology .7: 948.

12. Mahan ,N .E. yarcheski, A and yarcheski, T.J.(2010).Happiness as related to gender and health in early adolescents. Vol. 14,No.2,PP 175-190 
13. Oishi ,Sh. Kyungkoo, M \& Akimato ,Sh.(2010).Culture, interpersonal perceptions and happiness in social interactions. pres soc psuchol Bull.dio :10.111/01 46167207.No.3.PP.307-320.

14. Seligman, M.(1990).M.E.P. Learned optimism, New York, Random House.

15. Karimi, Ali.(1384)."study of the new methods of descriptive evaluation effect on students behavioral disorders of Shiraz elementary schools". Fars, Shiraz Ministry of Education Research Council . 